\title{
Effect of Approach Angle in Face Milling Using Tungsten Carbide Tool
}

\author{
Mulugundam Siva Surya ${ }^{1}$, Sridhar Atla ${ }^{2}$ \\ Assistant Professor, Mechanical Department, GITAM University, Hyderabad, Telangana.
}

\begin{abstract}
:
The influence of Approach angle of face milling cutter is investigated by conducting experiments with different approach angles in order to evaluate the effect of approach angle on productivity. The cartridges are designed, modeled and manufactured for having different approach angles when mounted on face milling cutter. The cutting forces, surface finish are measured in order to evaluate the performance of the cutter. The experiments are conducted on En31 steel material and optimized by using Taguchi technique. Taguchi method, a powerful tool to design optimization for quality, is used to find the optimal cutting parameters for milling operations. An orthogonal array signal to noise $(S / N)$ ratio and analysis of variance (ANOVA) are employed to investigate the cutting characteristics of EN 31 steel using tungsten carbide cutting tools. In this paper, not only the optimal cutting parameters for face milling operation are obtained, but also main cutting parameters that affect the cutting performance in machining operations can be found.
\end{abstract}

Keywords: Approach Angle, Surface Roughness, Taguchi technique.

\section{Introduction:}

Literature review reveals that lot of research work has done on influence of machining parameters, Tool wear, surface roughness, cutting forces, cutting temperatures. With various combinations of work pieces using coated and uncoated cutting Tools. Seref Aykut et al (2008) has investigated the effect of machining conditions (cutting speed, feed rate and depth of cut) on tool wear, chip morphology and cutting forces in symmetric face milling of cobalt base superalloy with physical vapour deposition coated and uncoated inserts. M.S. Kasim et al(2013) has done a work to estimate tool life of the end milled Inconel 718. The experiments were performed using TiAlN-coated carbide, milling parameters were the cutting speed, Vc, from 90 to $150 \mathrm{~m} / \mathrm{min}$; feed rate, fz, from 0.15 to $0.25 \mathrm{~mm} / \mathrm{rev}$; depth of cut, ap, from 0.3 to $0.5 \mathrm{~mm}$; and radial depth of cut, ae $=1 \mathrm{~mm}$. The application of the cutting fluid used in this experiment was a minimum quantity lubricant, which had the advantage of cooling effectiveness and low consumption of cutting fluid. The results showed that the feed rate, fz, was the primary factor controlling the tool life. The combination of $\mathrm{Vc}=115 \mathrm{~m} / \mathrm{min}, \mathrm{fz}=0.15 \mathrm{~mm} / \mathrm{tooth}$, as well as ap=0.5 $\mathrm{mm}$ and $\mathrm{ae}=0.15 \mathrm{~mm}$ gave the longest tool life that served $95.38 \mathrm{~min}$ in operation. No researcher investigated the influence of approach angle on material removal rate, cutting forces and surface roughness. In the current work the approach angle of end milling cutter is varied and its influence on various parameters is observed and optimization is done with Taguchi method. 


\subsection{Approach angle:}

Complimentary angle of lead angle is called approach angle Approach angle $=90^{\circ}$-lead angle

Approach angle is equal to the side cutting angle in single point cutting tool measured in ORS (Orthogonal Rake System).

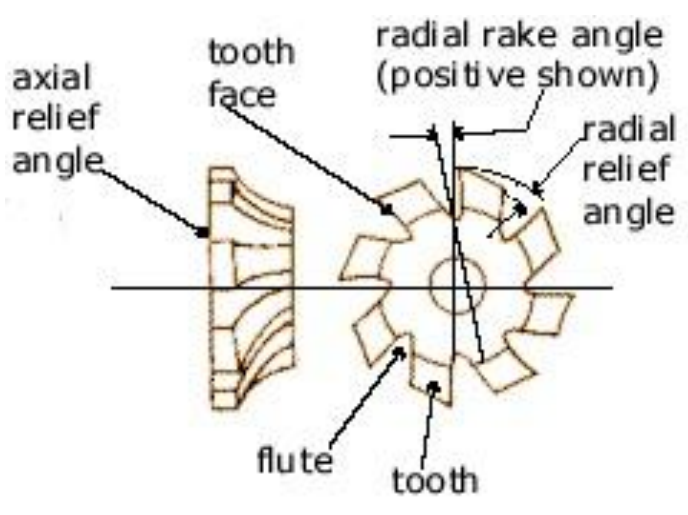

Fig.1. Milling Cutter Nomenclatures

Approach angle is the angle between a plane perpendicular to the cutter axis and a plane tangent to the surface of revolution of the cutting edges. In end mills and shoulder mills the approach angle is $90^{\circ}$. For face milling, the approach angles normally employed are $75^{\circ}, 60^{\circ}$ and $45^{\circ}$. The higher the approach angles the greater is the chip thickness for a given feed. As the approach angle decreases, the load on the cutting edge is distributed over a longer length of cutting edge. This reduces the thermal stresses and results in a slight improvement in the tool life.

By keeping the chip thickness constant, an increase in the approach angle permits the use of higher feeds resulting in higher productivity. For throwaway tipped cutters, a $75^{\circ}$ approach angle is most practical for roughing and interrupted cuts in general milling of steels. This allows higher depths of cut to be taken with a standard insert. An approach angle of $60^{\circ}$ is employed with positive axial and negative radial geometry and is recommended specially for milling of stainless steels. An approach angle of $45^{\circ}$ reduces chipping of cast iron work material. For fine finishing applications and for milling of stainless steels, an approach angle of $45^{\circ}$ is preferred.

Approach angles can range from zero to 45 degrees. The most common approach angles available on standard cutters are 0,15,30,45 degrees. Approach angles lesser than 45 degrees are usually considered special, and are used for very shallow cuts for fine finishing, or for cutting very hard work materials. Milling cutters with less approach angles also have greater heat dissipating capacity. Extremely high temperatures are generated at the insert cutting edge while the insert is in the cut. Carbide, as well as other tool materials, often softens when heated, and when a cutting edge is softened it will wear away more easily. However, if more of the tool can be employed in the cut, as in the case of lesser approach angles, the tool's heat dissipating capacity will be improved which, in turn, improves tool life. 


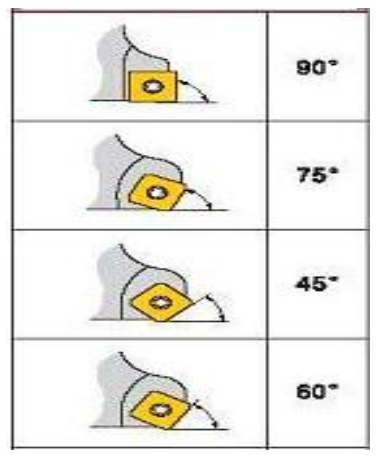

Fig 2. Approach angles

In addition, as approach angle is decreased, axial force is increased and radial force is reduced, important factors in controlling chatter. The use of less approach angle cutters is especially beneficial when machining materials with scaly or work hardened surfaces. With a less approach angle, the surface is spread over a larger area of the cutting edge. This reduces the detrimental effect on the inserts, extending tool life. The most obvious limitation on approach angle cutters is part configuration. If a square shoulder must be machined on a part, a 90 deg approach angle is required. It is impossible to produce a $90 \mathrm{deg}$ approach angle milling cutter with square shoulder is permissible. In this case $89 \mathrm{deg}$ approach angle cutter may be used.

\section{Experimental Work:}

\subsection{Procedural steps:}

1. Design of three cartridges of different approach angles.

2. Design the experiments with different parameters.

3. Conduct the experiments as per design.

4. Measure the cutting forces (kistler dynamometer).

5. Measure the surface finish (Handysurf).

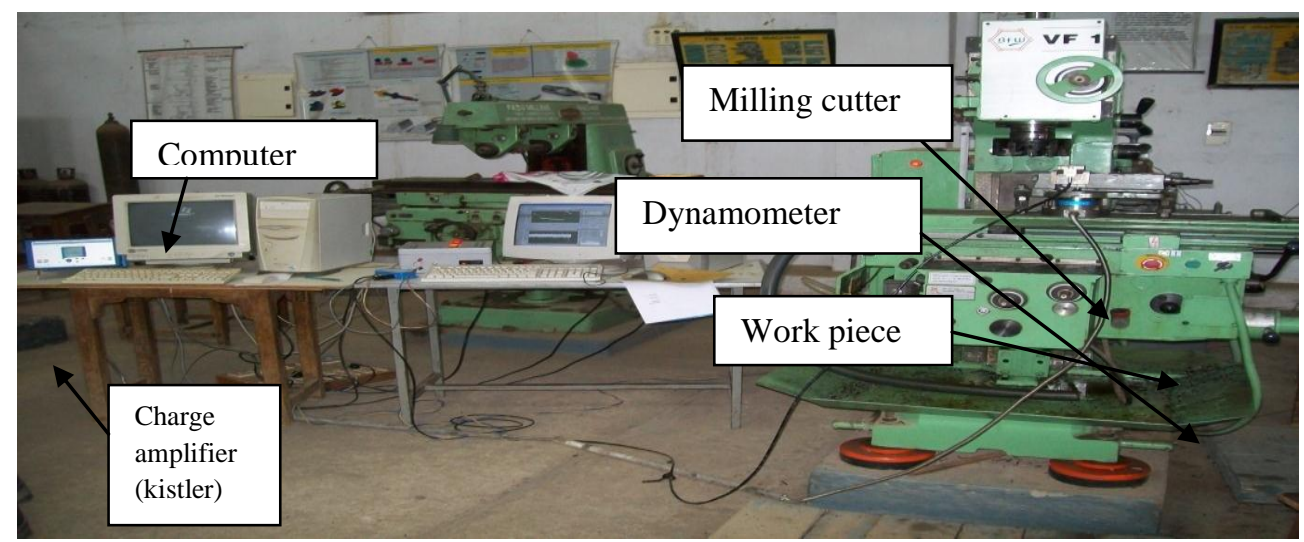

Fig 3. Experimental set up 


\subsection{Design of Cartridges:}

Three cartridges have been designed as shown in fig. 4 for M400 milling cutter for different approach angles and single tip seat design. The design of all cartridges is based on past drawings and design standards of Kennametal. The axial rake angle $-6^{0}$ and radial rake angle $-8^{0}$ are used for design. These two angles are provided on the tip seat of the cartridge. The design is carried for all the cartridges by maintaining the same axial and radial rake angle and only the approach angle is varied as shown in Fig.2. These two rake angle should same for all cartridges because these angles will influence the cutting forces the important dimensions, such as overall length of cartridge after fixing in the insert $(47 \mathrm{~mm}$ ), thickness of cartridge (which is measured from base to the highest point of insert-15.88mm), counter bore dimension, thickness $(15 \mathrm{~mm})$ and width $(20 \mathrm{~mm})$ of cartridges are kept constant for all cartridges. All the geometrical tolerances and surface finish value are specified and the drawings are released for manufacturing.42CrMo4 material is used for manufacturing cartridges. Hardness of material is around 40 to 44 HRC.

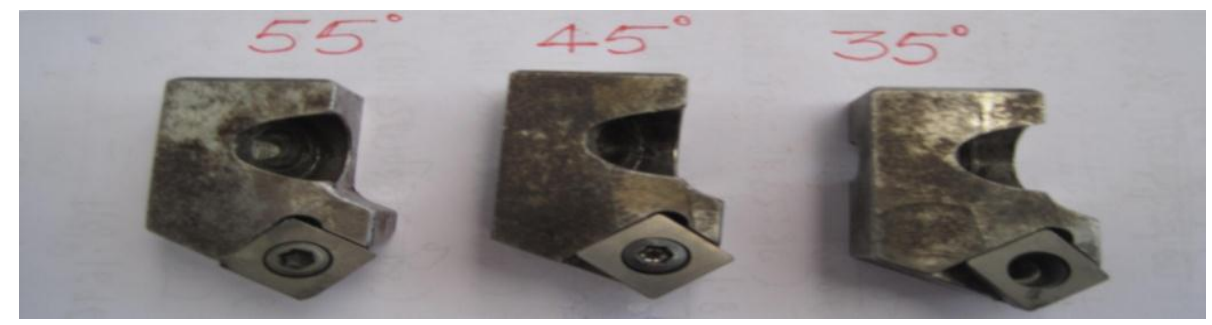

Fig.4 Cartridges

\subsection{Cutting Force And Surface Roughness Measurement:}

Machine tool

Work material

Tool material

Insert designation

Milling cutter

Cutting speeds (rpm)

Feed $(\mathrm{mm} / \mathrm{rev})$

Depth of cut (mm)

Approach angles (deg)
Vertical Milling Machine

EN 31

Tungsten Carbide

SPMW 120408 TTMS

WIDIA M400 Face milling cutter

$180,250,355$.

$0.1,0.2,0.3$.

$1,1.5,2$.

$35,45,55$.

\subsection{Work material specifications:}


International Journal of Recent advances in Mechanical Engineering (IJMECH) Vol.4, No.2, May 2015

\section{EN31:}

EN31 is a high carbon alloy steel which achieves a high degree of hardness with compressive strength and abrasion resistance. EN-31 steel is widely used in automotive industry for producing automotive components such as roller bearing, ball bearing, spline shaft, shearing blades, die parts etc. Therefore this steel is chosen for experimental investigation.

\subsubsection{Applications:}

Gas cylinders, Rollers \& chain links (conveyor belts), Structural tubing in cranes, bridges, platforms, Printing rollers, Flow lines, Guide rods in linear bearings, Pulley blanks.

Table .1 chemical compositions (Wt \%) of EN31

\begin{tabular}{|c|c|c|c|c|c|c|}
\hline Material & $\mathbf{C}$ & $\mathbf{M n}$ & $\mathbf{S i}$ & $\mathbf{C r}$ & $\mathbf{S}$ & $\mathbf{P}$ \\
\hline EN31 & $0.9-1.2$ & $0.3-0.75$ & $0.1-0.35$ & $1.0-1.6$ & 0.05 & 0.05 \\
\hline
\end{tabular}

Table. 2 Mechanical properties for En 31

\begin{tabular}{|l|l|}
\hline Poisson's ratio & 0.3 \\
\hline Elastic modulus(Gpa) & 202 \\
\hline Hardness(HB) & 290 \\
\hline Density(x1000kg/m $\left.{ }^{3}\right)$ & 8.745 \\
\hline Tensile strength(MPa) & 525.8 \\
\hline Yield strength(MPa) & 373.4 \\
\hline Elongation (\%) & 32.4 \\
\hline Reduction in area (\%) & 61.5 \\
\hline Impact strength(J) & 46.2 \\
\hline
\end{tabular}

\subsection{Tool Material:}

A tool material should have the requisite hardness,strength,thermal stability and ease in manufature and all this at an economic cost.

\subsubsection{Properties Of Tungsten Carbide:}

Material composition (Wt \%) - - WC-10wt\%Co, $0.6 \%$ others 
Density $\left(\mathrm{g} / \mathrm{cm}^{3}\right)$

Hardness (HRa)

Melting point $\left({ }^{\circ} \mathrm{C}\right)$

Transverse rupture strength (MPa)

Compressive strength (MPa)

Thermal expansion coefficient $\left(\mathrm{K}^{-1}\right)$

\section{5}

92.3

2597

4000

6600

$5.5 \times 10^{-6}$

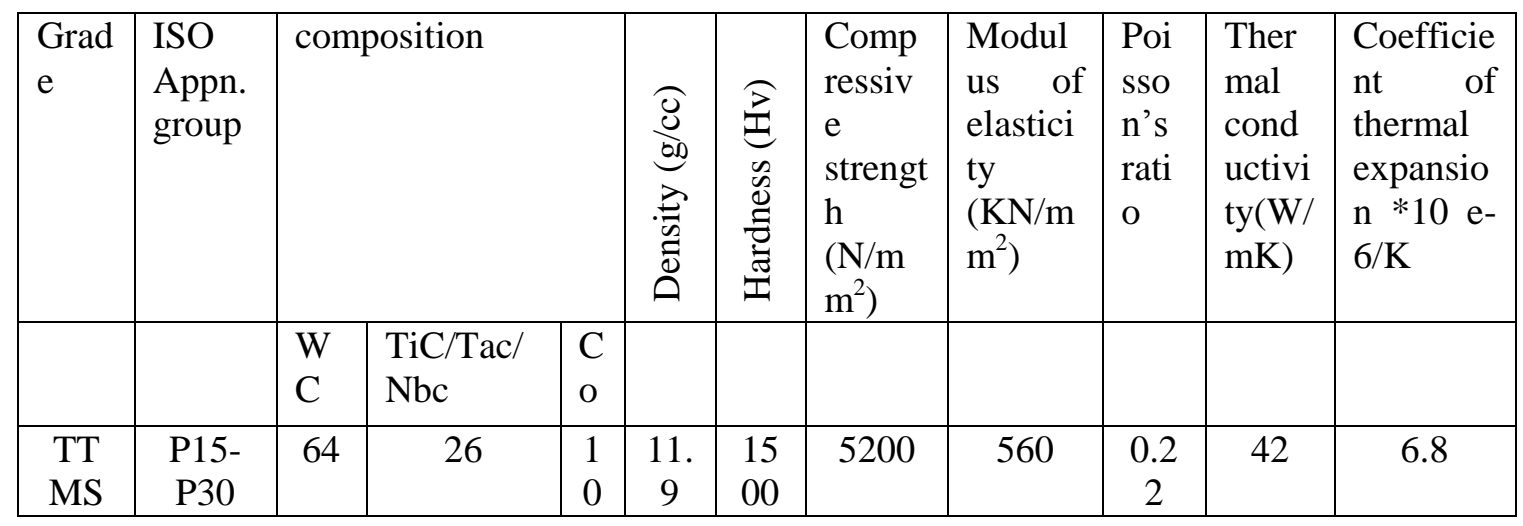

\subsubsection{Milling Cutter:}

For conducting experiments M400 face milling cutter of Dia $150 \mathrm{~mm}$ is used as shown in the fig.5. M400, the cartridge based milling system has been developed for flexibility. Whether it is face milling or square shoulder milling, roughing or finishing, the M400 system meets the entire requirement. The design features replaceable cartridges which accept various types of insert from WIDIA standard milling range.

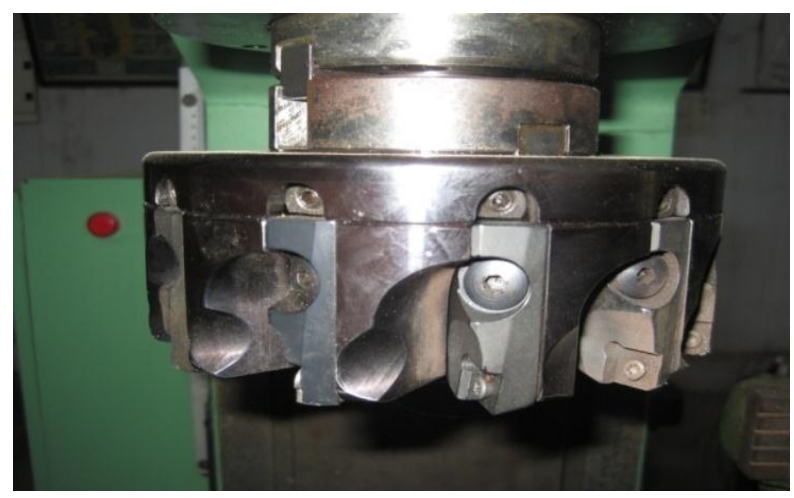

Fig.5. M400 Milling cutter 
The cartridges are fitted securely on the cutter body by means of high tensile M8 screw. Axial positioning is assured by a locating ring bolted on the cutter body. Twelve different types of cutters can be made from single cutter body by changing only the cartridges and inserts. This flexibility helps to create the right for any given application.

\subsection{Surface Finish Measurement}

Handysurf instrument: Handysurf instrument is widely used to measure the shape or form of components.

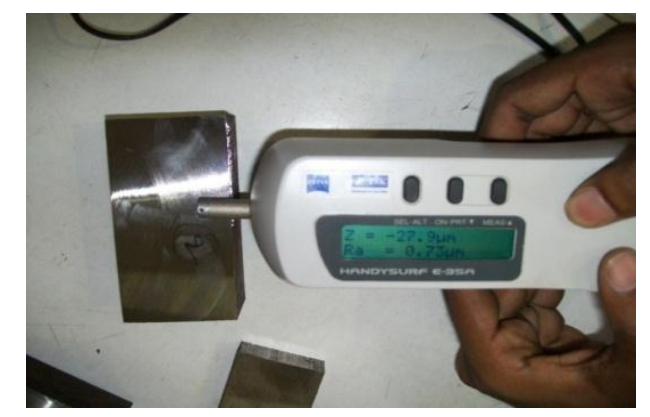

Fig .6 Measuring surface roughnesses by using Handysurf

\section{Work Material Preparation:}

The raw work material of size is $100 \times 100 \times 500 \mathrm{~mm}$; it is cut into required dimension $50 \times 50 \times$ $80 \mathrm{~mm}$, with help of power hacksaw, shaping machine and milling machine

Table.3. Inputs values for Experiments

\begin{tabular}{|l|l|l|l|l|l|l|l|l|}
\hline Sl.no & $\begin{array}{l}\text { App. } \\
\text { angle }\end{array}$ & $\begin{array}{l}\text { Speed } \\
(\mathrm{rpm})\end{array}$ & $\begin{array}{l}\text { Feed rate } \\
(\mathrm{mm} / \mathrm{min})\end{array}$ & $\begin{array}{l}\text { Depth } \\
\text { of cut } \\
(\mathrm{mm})\end{array}$ & $\begin{array}{l}\text { Surf } \\
\text { rough } \\
(\mu \mathrm{m})\end{array}$ & $\begin{array}{l}\text { MRR } \\
\left(\mathrm{mm}^{3} / \mathrm{min}\right)\end{array}$ & $\begin{array}{l}\text { Fx } \\
(\mathrm{N})\end{array}$ & $\begin{array}{l}\text { Fy } \\
(\mathrm{N})\end{array}$ \\
\hline 1 & 35 & 180 & 20 & 1 & 0.39 & 1700 & 702 & 650 \\
\hline 2 & 35 & 250 & 50 & 1.5 & 0.36 & 7500 & 1574 & 1233 \\
\hline 3 & 35 & 355 & 100 & 2 & 0.56 & 20000 & 1990 & 1381 \\
\hline 4 & 45 & 180 & 40 & 2 & 0.81 & 8000 & 1657 & 1112 \\
\hline 5 & 45 & 250 & 80 & 1 & 0.62 & 6800 & 1381 & 1542 \\
\hline 6 & 45 & 355 & 40 & 1.5 & 0.78 & 5100 & 931 & 775 \\
\hline 7 & 55 & 180 & 50 & 1.5 & 0.93 & 6375 & 1493 & 1286 \\
\hline
\end{tabular}


International Journal of Recent advances in Mechanical Engineering (IJMECH) Vol.4, No.2, May 2015

\begin{tabular}{|l|l|l|l|l|l|l|l|l|}
\hline 8 & 55 & 250 & 25 & 2 & 0.33 & 5000 & 965 & 828 \\
\hline 9 & 55 & 355 & 80 & 1 & 0.585 & 6800 & 1083 & 1240 \\
\hline
\end{tabular}

Table .4.S/N response table for surface roughness

Table .4.S/N response table for surface roughness

\section{RESULTS AND DISCUSSIONS:}

Experiments were carried out based on the experimental Table 3.2 mentioned in the previous chapter and the result ware tabulated in the following tables.

Table.5. S/N response table for surface roughness

\begin{tabular}{|c|c|c|c|c|c|c|c|c|c|c|c|c|}
\hline 1 & 35 & 180 & 20 & 1 & 0.39 & 1700 & 702 & 650 & 8.18 & $\begin{array}{l}64.6 \\
1\end{array}$ & $\begin{array}{l}- \\
56.93\end{array}$ & $\begin{array}{l}- \\
56.26\end{array}$ \\
\hline 2 & 35 & 250 & 50 & 1.5 & 0.36 & 7500 & $\begin{array}{l}157 \\
4\end{array}$ & $\begin{array}{l}123 \\
3\end{array}$ & 8.87 & 77.5 & $\begin{array}{l}- \\
63.94\end{array}$ & $\begin{array}{l}- \\
61.82\end{array}$ \\
\hline 3 & 35 & 355 & 100 & 2 & 0.56 & $\begin{array}{l}2000 \\
0\end{array}$ & $\begin{array}{l}199 \\
0\end{array}$ & $\begin{array}{l}138 \\
1\end{array}$ & 5.04 & $\begin{array}{l}86.0 \\
2\end{array}$ & $\begin{array}{l}- \\
65.98\end{array}$ & $\begin{array}{l}- \\
62.80\end{array}$ \\
\hline 4 & 45 & 180 & 40 & 2 & 0.81 & 8000 & $\begin{array}{l}165 \\
7\end{array}$ & $\begin{array}{l}111 \\
2\end{array}$ & 1.83 & $\begin{array}{l}78.0 \\
6\end{array}$ & $\begin{array}{l}- \\
64.39\end{array}$ & $\begin{array}{l}- \\
60.92\end{array}$ \\
\hline 5 & 45 & 250 & 80 & 1 & 0.62 & 6800 & $\begin{array}{l}138 \\
1\end{array}$ & $\begin{array}{l}154 \\
2\end{array}$ & 4.15 & $\begin{array}{l}76.6 \\
5\end{array}$ & $\begin{array}{l}- \\
62.80\end{array}$ & $\begin{array}{l}- \\
63.76\end{array}$ \\
\hline 6 & 45 & 355 & 40 & 1.5 & 0.78 & 5100 & 931 & 775 & 2.16 & $\begin{array}{l}74.1 \\
5 \\
\end{array}$ & $\begin{array}{l}- \\
59.38\end{array}$ & $\begin{array}{l}- \\
57.79 \\
\end{array}$ \\
\hline 7 & 55 & 180 & 50 & 1.5 & 0.93 & 6375 & $\begin{array}{l}149 \\
3\end{array}$ & $\begin{array}{l}128 \\
6\end{array}$ & 0.63 & $\begin{array}{l}76.0 \\
9\end{array}$ & $\begin{array}{l}- \\
63.48\end{array}$ & -62.18 \\
\hline 8 & 55 & 250 & 25 & 2 & 0.33 & 5000 & 965 & 828 & 9.63 & $\begin{array}{l}73.9 \\
8\end{array}$ & $\begin{array}{l}- \\
59.69\end{array}$ & $\begin{array}{l}- \\
58.36\end{array}$ \\
\hline 9 & 55 & 355 & 80 & 1 & $\begin{array}{l}0.58 \\
5\end{array}$ & 6800 & $\begin{array}{l}108 \\
3\end{array}$ & $\begin{array}{l}124 \\
0\end{array}$ & 4.73 & $\begin{array}{l}76.6 \\
5\end{array}$ & $\begin{array}{l}- \\
60.69\end{array}$ & $\begin{array}{l}- \\
61.87\end{array}$ \\
\hline & \multicolumn{3}{|c|}{ parameter } & \multicolumn{2}{|c|}{ Level1 } & \multicolumn{2}{|c|}{ Level 2} & \multicolumn{2}{|c|}{ Level 3} & \multicolumn{2}{|c|}{ Max-min } & \\
\hline & \multicolumn{3}{|c|}{ Approach angle } & \multicolumn{2}{|c|}{7.363} & \multicolumn{2}{|c|}{2.714} & \multicolumn{2}{|c|}{4.997} & \multicolumn{2}{|c|}{4.649} & \\
\hline & \multicolumn{3}{|c|}{ Cutting speed } & \multicolumn{2}{|c|}{3.456} & \multicolumn{2}{|c|}{7.552} & \multicolumn{2}{|c|}{3.975} & \multicolumn{2}{|c|}{4.005} & \\
\hline & \multicolumn{3}{|c|}{ Feed rate } & \multicolumn{2}{|c|}{6.656} & \multicolumn{2}{|c|}{5.145} & \multicolumn{2}{|c|}{3.273} & \multicolumn{2}{|c|}{3.383} & \\
\hline
\end{tabular}




\begin{tabular}{|l|l|l|l|l|}
\hline Depth of cut & $\mathbf{5 . 6 8 7}$ & 3.887 & 5.499 & 1.80 \\
\hline
\end{tabular}

\section{Average $\mathbf{= 5 . 0 2 4 \mathrm { dB }}$}

Optimum cutting parameters are Approach angle $=35^{\circ}$

Cutting speed $=250 \mathrm{rpm}$

Feed rate $\quad=0.1 \mathrm{~mm} / \mathrm{rev}$

Depth of cut $=1 \mathrm{~mm}$

$\mathrm{S} / \mathrm{N}$ ratio for surface roughness:

Smaller the better i.e. $\mathrm{S} / \mathrm{N}$ ratio $=-10 \log (\mathrm{MSD})$

$$
\begin{gathered}
\mathrm{MSD}=(1 / \mathrm{m})^{*} \sum_{i=1}^{m}\left(\mathrm{~S}_{i}^{2}\right) \\
\mathrm{S} / \mathrm{N} 1=-10 \log \left(0.39^{2}\right) \\
=8.18 \mathrm{~dB}
\end{gathered}
$$

$\mathrm{S} / \mathrm{N} \mathrm{P} 1,1=(\mathrm{SN} 1+\mathrm{SN} 2+\mathrm{SN} 3) / 3$

$=(8.18+8.87+5.04) / 3$

$=7.363 \mathrm{~dB}$

Average $=(\mathrm{SN} 1+\mathrm{SN} 2+\mathrm{SN} 3+\mathrm{SN} 4+\mathrm{SN} 5+\mathrm{SN} 6+\mathrm{SN} 7+\mathrm{SN} 8+\mathrm{SN} 9) / 9$

$\mathrm{n}_{\mathrm{m}}=(8.18+8.87+5.04+1.83+4.15+2.16+0.63+9.63+4.73) / 9$ $=5.024 \mathrm{~dB}$

$\mathrm{DOF}=$ Level $-1=3-1=2$

Sum of squares $=(\text { total of A } 1)^{2} / \mathrm{n} 1+(\text { total of A2 })^{2} / \mathrm{n} 2+(\text { total of A3 })^{2} / \mathrm{n} 3-(\text { total of A })^{2} / \mathrm{n}$

$$
\mathrm{SS}_{\mathrm{d}}=32.43 \mathrm{~dB}
$$

Mean squares $=$ Sum of squares $/ \mathrm{DOF}$

$$
\begin{aligned}
& =32.43 / 2 \\
& =16.21 \mathrm{~dB}
\end{aligned}
$$

Sum of squares of Total $=\sum_{i=1}^{n}\left(n_{m}-n_{i}\right)^{2}$

$$
\mathrm{SS}_{\mathrm{t}}=84.58
$$

Sum of squares of error $=\left(\mathrm{SS}_{\mathrm{t}}-\left(\mathrm{SSd}_{1}+\mathrm{SSd}_{2}+\mathrm{SSd}_{3}\right)\right)$

$$
=0.1
$$

Mean squares of error $=($ Sum of squares of error/ DOF $)$

$$
=0.1 / 2
$$

$\mathrm{SSe}=0.05$

$\mathrm{F}=($ Mean squares of P1/ Mean squares of error $)$

$=16.21 / 0.05$

$=324.2$

$\mathrm{P}=($ Sum of squares/ Sum of squares of Total $)$

$=32.43 / 84.58=38.34 \%$

Table.6. ANOVA for surface roughness:

\begin{tabular}{|l|l|l|l|l|l|}
\hline Parameter & DOF & SS & MS & F & P \\
\hline Approach angle & 2 & 32.43 & 16.21 & 324.2 & 38.34 \\
\hline Cutting speed & 2 & 29.02 & 14.51 & 290.2 & 34.32 \\
\hline Feed rate & 2 & 17.2 & 8.6 & 172 & 20.34 \\
\hline Depth of cut & 2 & 5.9 & 2.9 & 58 & 6.98 \\
\hline Error & 2 & 0.1 & 0.05 & - & 0.12 \\
\hline Total & 10 & 84.58 & - & - & 100 \\
\hline
\end{tabular}


Predicted surface roughness:

$\mu($ predicted $\mathrm{S} / \mathrm{N}$ ratio $)=\mathrm{Y}+(\mathrm{A} 1-\mathrm{Y})+(\mathrm{B} 2-\mathrm{Y})+(\mathrm{C} 1-\mathrm{Y})+(\mathrm{D} 1-\mathrm{Y})$ $=5.024+(7.363-5.024)+(7.552-5.024)+(6.656-5.024)+(5.687-5.024)$

$\mu=-10 \log \left(\mathrm{Ra}^{2}\right)$ $=12.19 \mathrm{~dB}$

$12.19=-10 \log \left(\mathrm{Ra}^{2}\right)$

$\left(\mathrm{Ra}^{2}\right)=0.06$

$\mathrm{Ra}=\mathbf{0 . 2 4 5} \mu \mathrm{m}$.

Table.7. S/N response table for MRR:

\begin{tabular}{|l|l|l|l|l|}
\hline parameter & Level1 & Level 2 & Level 3 & Max-min \\
\hline Approach angle & 76.04 & $\mathbf{7 6 . 2 9}$ & 75.57 & 0.71 \\
\hline Cutting speed & 72.92 & 76.04 & $\mathbf{7 8 . 9 4}$ & 6.02 \\
\hline Feed rate & 7.91 & 77.4 & $\mathbf{7 9 . 6}$ & 8.67 \\
\hline Depth of cut & 72.64 & 75.91 & $\mathbf{7 9 . 3 5}$ & 6.72 \\
\hline
\end{tabular}

Average $=\mathbf{7 5 . 9 7} \mathrm{dB}$

Optimum cutting parameters are Approach angle $=45^{\circ}$

Cutting speed $=355 \mathrm{rpm}$

Feed rate $\quad=0.3 \mathrm{~mm} / \mathrm{rev}$

Depth of cut $=2 \mathrm{~mm}$

Table.8. ANOVA of MRR:

\begin{tabular}{|l|l|l|l|l|l|}
\hline Parameter & DOF & SS & MS & F & P \\
\hline Approach angle & 2 & 0.8 & 0.4 & 0.1 & 0.325 \\
\hline Cutting speed & 2 & 54.4 & 27.2 & 68 & 23.9 \\
\hline Feed rate & 2 & 122.1 & 61.1 & 152.7 & 49.67 \\
\hline Depth of cut & 2 & 67.7 & 33.9 & 84.75 & 27.54 \\
\hline Error & 2 & 0.8 & 0.4 & - & 1.45 \\
\hline Total & 10 & 245.8 & - & - & 100 \\
\hline
\end{tabular}

Predicted MRR:

$\mu($ predicted S/N ratio $)=\mathrm{Y}+(\mathrm{A} 2-\mathrm{Y})+(\mathrm{B} 3-\mathrm{Y})+(\mathrm{C} 3-\mathrm{Y})+(\mathrm{D} 3-\mathrm{Y})$

$$
=86.27 \mathrm{~dB}
$$

$\mu=-10 \log \left(1 /\right.$ predicted $\left.\mathrm{MRR}^{2}\right)$

$86.27=-10 \log \left(1 / \mathrm{MRR}^{2}\right)$

$\mathrm{MRR}=\mathbf{2 0 5 8 2 . 5 9} \mathrm{mm}^{3} / \mathrm{min}$

Table.9. S/N response table for feed force (fx):

\begin{tabular}{|l|l|l|l|l|}
\hline parameter & Level1 & Level 2 & Level 3 & Max-min \\
\hline Approach angle & -62.28 & -62.19 & $\mathbf{- 6 1 . 2 9}$ & 0.99 \\
\hline Cutting speed & $\mathbf{- 6 1 . 6 0}$ & -62.14 & -62.02 & 0.55 \\
\hline Feed rate & $\mathbf{- 5 8 . 6 7}$ & -63.01 & -64.09 & 5.42 \\
\hline Depth of cut & $\mathbf{- 6 0 . 1 4}$ & -62.27 & -63.35 & 3.21 \\
\hline
\end{tabular}


Average $=\mathbf{- 6 4 . 9 6} \mathrm{dB}$

Optimum cutting parameters are Approach angle $=55^{\circ}$

$$
\begin{array}{ll}
\text { Cutting speed } & =180 \mathrm{rpm} \\
\text { Feed rate } & =0.1 \mathrm{~mm} / \mathrm{rev} \\
\text { Depth of cut } & =1.0 \mathrm{~mm} \\
\text { Table.10. Anova for feed force (fx): }
\end{array}
$$

\begin{tabular}{|l|l|l|l|l|l|}
\hline Parameter & DOF & SS & MS & F & P \\
\hline Approach angle & 2 & 1.8 & 0.9 & 22.5 & 2.65 \\
\hline Cutting speed & 2 & 0.5 & 0.25 & 6.25 & 0.74 \\
\hline Feed rate & 2 & 49.41 & 24.7 & 617.5 & 72.96 \\
\hline Depth of cut & 2 & 16.02 & 8.01 & 200.25 & 23.64 \\
\hline Error & 2 & 0.08 & 0.04 & - & 0.118 \\
\hline Total & 10 & 67.72 & - & - & 100 \\
\hline
\end{tabular}

Predicted FEED FORCE Fx:

$\mu($ predicted $\mathrm{S} / \mathrm{N}$ ratio $)=\mathrm{Y}+(\mathrm{A} 3-\mathrm{Y})+(\mathrm{B} 1-\mathrm{Y})+(\mathrm{C} 1-\mathrm{Y})+(\mathrm{D} 1-\mathrm{Y})$

$\mu=-10 \log \left(\right.$ predicted $\left.\mathrm{Fx}^{2}\right)$

$$
=-55.94 \mathrm{~dB}
$$

$-55.94=-10 \log \left(\mathrm{Fx}^{2}\right), \mathrm{Fx}=\mathbf{6 2 6 . 6 N}$

Table.11. S/N response table for tangential force (fy):

\begin{tabular}{|l|l|l|l|l|}
\hline parameter & Level1 & Level 2 & Level 3 & Max-min \\
\hline Approach angle & $\mathbf{- 6 0 . 2 9}$ & -60.82 & -60.80 & 0.53 \\
\hline Cutting speed & $\mathbf{- 5 9 . 7 9}$ & -61.31 & -60.82 & 1.53 \\
\hline Feed rate & $\mathbf{- 5 7 . 4 7}$ & -61.54 & -62.92 & 5.45 \\
\hline Depth of cut & -60.63 & $\mathbf{- 6 0 . 6 0}$ & -60.7 & 0.1 \\
\hline
\end{tabular}

Average $=\mathbf{- 6 0 . 6 4} \mathrm{dB}$

Optimum cutting parameters are Approach angle $=35^{\circ}$

Cutting speed $=180 \mathrm{rpm}$

Feed rate $\quad=0.1 \mathrm{~mm} / \mathrm{rev}$

Depth of cut $=1.5 \mathrm{~mm}$

Table.12. Anova for tangential force (fy):

\begin{tabular}{|l|l|l|l|l|l|}
\hline Parameter & DOF & SS & MS & F & P \\
\hline Approach angle & 2 & 0.543 & 0.27 & 5.4 & 1.03 \\
\hline Cutting speed & 2 & 3.64 & 1.82 & 36.4 & 6.95 \\
\hline Feed rate & 2 & 48.062 & 24.031 & 480.62 & 91.82 \\
\hline Depth of cut & 2 & 0.014 & 0.007 & 0.14 & 0.026 \\
\hline
\end{tabular}




\begin{tabular}{|l|l|l|l|l|l|}
\hline Error & 2 & 0.1 & 0.05 & - & 0.19 \\
\hline Total & 10 & 52.34 & - & - & 100 \\
\hline
\end{tabular}

Predicted TANGENTIAL FORCE (Fy):

$\mu($ predicted $\mathrm{S} / \mathrm{N}$ ratio $)=\mathrm{Y}+(\mathrm{A} 1-\mathrm{Y})+(\mathrm{B} 1-\mathrm{Y})+(\mathrm{C} 1-\mathrm{Y})+(\mathrm{D} 2-\mathrm{Y})$

$\mu=-10 \log \left(\right.$ predicted $\mathrm{Fy}^{2}$ )

$$
=-56.23 \mathrm{~dB}
$$

$-56.23=-10 \log \left(\mathrm{Fy}^{2}\right)$

$\mathrm{Fy}=\mathbf{6 4 7 . 8 9} \mathrm{N}$

By using Taguchi optimization technique, the results are

1. From the analysis of surface roughness, we can observe that the cutting parameters, Approach angle $(\mathrm{P}=38.34 \%)$, Cutting speed $(\mathrm{P}=34.32 \%)$, Feed $(\mathrm{P}=20.34 \%)$, depth of cut $(\mathrm{P}=6.98 \%)$ have statistical and physical significance on the surface roughness obtained, especially the Approach angle.

2. From the analysis of Material Removal Rate (MRR), we can observe that the cutting parameters, Approach angle $(\mathrm{P}=0.325 \%)$, cutting speed $(\mathrm{P}=23.9 \%)$, Feed $(\mathrm{P}=49.67 \%)$, depth of cut $(\mathrm{P}=27.54 \%)$, have statistical and physical significance on the MRR obtained, especially the feed.

3. From the analysis of Feed force $(\mathrm{Fx})$, we can observe that the cutting parameters, Approach angle $(\mathrm{P}=2.65 \%)$, cutting speed $(\mathrm{P}=0.74 \%)$, Feed $(\mathrm{P}=72.96 \%)$, depth of cut $(\mathrm{P}=23.64 \%)$, have statistical and physical significance on the Fx obtained, especially the feed.

4. From the analysis of Cutting force $(\mathrm{Fy})$, we can observe that the cutting parameters, Approach angle $(\mathrm{P}=1.03 \%)$, cutting speed $(\mathrm{P}=6.95 \%)$, Feed $(\mathrm{P}=91.82 \%)$, depth of cut $(\mathrm{P}=0.026 \%)$, have statistical and physical significance on the Fy obtained, especially the feed.

\section{CONCLUSIONS}

The surface roughness increases as the approach angle is increased. This is due to the increase in the thickness of uncut ridge as the angle between the secondary cutting edge and the machined surface increases with the increase in approach angle. The results show that MRR increases with the increase in speed, feed and depth of cut, feed being the most significant factor. It was observed that $45^{\circ}$ is the optimum approach angle for maximum material removal rate and hence manufacturers most commonly use $45^{\circ}$ approach angles for rough milling operations. It is found that feed is the most significant parameter for feed force $\left(\mathrm{F}_{\mathrm{x}}\right)$ and cutting force $\left(\mathrm{F}_{\mathrm{y}}\right)$ as compared to the cutting speed, approach angle and depth of cut. It is also observed that feed force decreases with the increase in approach angle whereas cutting force decreases with the decrease in approach angle, this is due to the load on the cutting edge is distributed over a long length of cutting edge.

\section{REFERENCES:}


[1] M. V. R. D. Prasad et al, Experimental investigation to study the influence of process parameters in dry machining, ARPN Journal of Engineering and Applied Sciences (2009).

[2] Taguchi Techniques for Total Quality Management by Philip. J. Ross, Second Edition, Tata McGrawHill.

[3] Seref Aykut et al, Experimental observation of tool wear, cutting forces and chip morphology in face milling of cobalt based super-alloy with physical vapour deposition coated and uncoated tool, Materials and Design 28 (2007) 1880-1888.

[4] H.Z. Li et al, An experimental study of tool wear and cutting force variation in the end milling of Inconel 718 with coated carbide inserts, Journal of Materials Processing Technology 180 (2006) 296304.

[5] S. Aykut et al, Modelling of cutting forces as function of cutting parameters for face milling of satellite 6 using an artificial neural network, Journal of Materials Processing Technology190(2007)199-203.

[6] A. Rosales et al, Prediction of Surface Roughness by Registering Cutting Forces in the Face Milling Process, European Journal of Scientific Research ISSN 1450-216X Vol.41 No.2 (2010), pp.228-237.

[7] Production technology, hmt, Tata McGraw-Hill Publishing Company Limited.

[8] Muammer Nalbant et al, The effect of coating material and geometry of cutting tool and cutting speed on machinability properties of Inconel 718 super alloys, Materials and Design 28 (2007) 1719-1724.

[9] P.G. Benardos, G.C. Vosniakos, Prediction of surface roughness in CNC face milling using neural networks and Taguchi's design of experiments, Robotics and Computer Integrated Manufacturing 18 (2002) 343-354.

[10] P. Wilkinson et al, Surface finish parameters as diagnostics of tool wear in face milling, Wear 205(1997) 47-54.

\section{Author}

Mulugundam Siva Surya Completed M.Tech From Nit Warangal,India, Currently Working As Assistant Professor In Mechanical Department, Gitam University, Hyderabad Campus, Hyderabad, India.

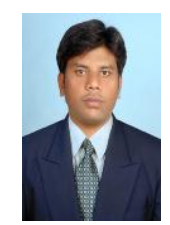

